\title{
Единство и своеобразие современных этнических культур народов Центральной Азии: три исследовательских проблемных поля
}

\author{
Чимиза К. Ламажаа \\ Калмыцкий научный цеентр Российской академии наук, Российская Федерация
}

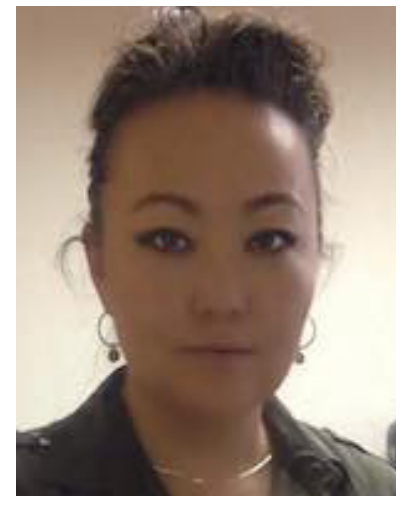

В статье анализируются разные подходы к изучению единства и своеобразия современных кочевых культур Центральной Азии (тувинцев, калмыков, монголов, хакасов, алтайцев и др.), применяемые российскими учеными, начиная с XIX в. В центре анализа - публикации культурологической познавательной области, в которых изучается ценностно-смысловое ядро культур. Массив публикаций разделен на три условных больших исследовательских поля, которые соответствуют определенным этапам развития научного знания: 1) поле сравнительно-исторических исследований, 2) поле исследований универсалий культур и 3) поле исследований уникалий и универсалий культур с особенностями эмико-этических подходов.

В статье рассмотрены особенности каждого исследовательского поля на примере подходов отдельных монографий, статей, сборников.

Поле сравнительно-исторического анализа (появилось с ХІХ и присутствует до сегодняшнего дня) содержит работы с историко-типологическими, историко-генетическими сравнениями и обобщениями. Общим можно назвать различение двух культурных ареалов территории - по языковым группам: тюркской и монгольской. Поле исследований универсалий культуры развернулось с 1980-х годов. В нем рассматриваются общие, универсальные категории всех культур. С начала ХХІ в. появилось и стало расширяться исследовательское поле, в котором оказались и универсалии, и уникалии культуры, однако важным моментом, отличающим данное поле, стала субъектность исследователя и то, какую методологическую позицию он выбирает. В этом поле особенности изучения культур определяются в эмикоэтических аспектах исследовательских подходов.

Ключевые слова: Центральная Азия; Саяно-Алтайский регион; Россия; Монголия; тувинцы; калмыки; монголы; хакасы; алтайцы; история этнографии; российская этнография; сравнительно-исторический анализ; универсалии культуры; кросс-культурное исследование; эмическое исследование

Исследование выполнено в рамках государственной субсидии - проект «Комплексное исследование процессов общественнополитического и культурного развития народов Юга России» (№ госрегистрации: ААAА-A19-119011490038-5).

\section{Для цитирования:}

Ламажаа Ч. К. Единство и своеобразие современных этнических культур народов Центральной Азии: три исследовательских проблемных поля // Новые исследования Тувы. 2020, № 4. С. 201-216. DOI: www.doi.org/10.25178/nit.2020.4.14

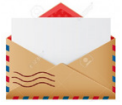

Ламажаа Чимиза Кудер-ооловна - доктор философских наук, ведущий научный сотрудник отдела археологии, этнологии и антропологии Калмыцкого научного центра РАН. Адрес: 358000, Россия, г. Элиста, ул. И. К. Илишкина, д. 8. Тел.: +7 (916) 413-33-85. Эл. адрес: lamazhaа@tuva.asia

LAMAZHAA, Chimiza Kuder-oolovna, Doctor of Philosophy, Leading Researcher, Department of Archeology, Ethnology and Antropology, Kalmyk Scientific Center, Russian Academy of Sciences. Postal address: 8 I. K. Ilishkina St., Elista, 358000, Russian Federation. Tel.: +7 (916) 413-33-85. E-mail: lamazhaa@tuva.asia ORCID ID: 0000-0003-1813-3605 


\title{
Unity and uniqueness of contemporary ethnic cultures of Central Asia: three research problem fields
}

\author{
Chimiza K. Lamazhaa \\ Kalmyk Scientific Centre, Russian Academy of Sciences, Russian Federation
}

The article looks at various approaches to the study of the unity and uniqueness of modern nomadic cultures of Central Asia (Tuvan, Kalmyk, Mongol, Khakass, Altai etc.), developed by Russian scholars since the 19th century. Our analysis focuses on published works in the field of culturology that studied the value-semantic cultural core. These publications can be divided into three large research fields which match a specific stage of academic knowledge development: 1) the field of comparative history; 2) the field of studying the universals of culture, and 3) that dealing with both universals and unique features of culture, making use of the emic and ethical approaches. The article examines each of the fields by studying sample approaches in individual monographs, articles, and collections.

The field of comparative historical analysis has been around since the 19th century and includes studies developing historicaltypological and historical-genetic comparisons and generalizations. The common feature here is the distinction between two language groups (Turkic and Mongolian) representing two diverse cultural areas. The field of studying cultural universals arose in 1980s and focuses on universal categories common for all cultures. In early 21st century, a new field followed suit, the one which covered both cultural universals and unique elements. Its distinctive element is the subjectivity of researchers and an opportunity for then to select a methodological stance. Within this field, details of studying cultures are determined by the emic and ethical aspects of research approaches.

Keywords: Central Asia; Sayano-Altai region; Russia; Mongolia; Tuvans; Kalmyks; Mongols; Khakass; Altaians; history of Russian ethnography; comparative historical analysis; cultural universals; cross-cultural study; emic study

\section{Financing}

The reported study was funded by government subsidy - project name 'Socio-Political and Cultural Development of South Russia's Peoples: a Comprehensive Research of Respective Processes’ (state reg. no. AAAA-A19-119011490038-5).

\section{For citation:}

Lamazhaa Ch. K. Edinstvo i svoeobrazie sovremennykh etnicheskikh kul'tur narodov Tsentral'noi Azii: tri issledovatel'skikh problemnykh polia [Unity and uniqueness of contemporary ethnic cultures of Central Asia: three research problem fields]. New Research of Tuva, 2020, no. 4, pp. 201-216. (In Russ.). DOI: www.doi.org/10.25178/nit.2020.4.14

\section{Введение}

В центре внимания данной статьи - проблематика исследований вопросов единства и своеобразия кочевых культур Центральной Азии ${ }^{1}$ (тувинцев, калмыков, монголов, хакасов, алтайцев и др.), выполняемых российскими учеными. За всю свою многовековую историю существования, развития данные культуры формировались в условиях сходных хозяйственно-культурных типов (с кочевым скотоводством как ведущим типом производящего хозяйства) и постоянного взаимовлияния. Также важным фактором единства являются особенности этногенеза народов региона, начало которого у многих народов восходит к истории древних и раннесредневековых номадов. Эти обстоятельства определили их близость и значительную схожесть в ряде культурных элементов и форм. Тем не менее, история формирования каждого этноса, социально-политические события в регионе определили и особые пути развития их языков, и своеобразие их материальной культуры, и особенности традиционной обрядности. Поэтому вопросы сравнений, сопоставлений отмечаются практически в любом научном исследовании, даже если оно посвящено непосредственно отдельно взятой этнической культуре.

\footnotetext{
${ }^{1}$ Географическая трактовка Центральной Азии в российской и зарубежной науке различна. Я придерживаюсь традиций советской-российской литературы, в которой к Центральной Азии относятся следующие территории: Монголия; китайские регионы - Внутренняя Монголия, Синьцзян-Уйгурский автономный район, провинция Ганьсу, северная часть провинции Цинхай, значительная часть провинции Шэнси; из российских территорий Тува, значительные территории прибайкальских регионов и Южного Алтая, то есть Саяно-Алтайский регион (Грач, 1984: 114).
} 
Как мы знаем, представления о культурах на начальных этапах развития западной науки в XVII-XIX вв. содержали значительный отпечаток этноцентричности самих исследователей, прежде всего представителей иных культур. Поэтому сравнения делались в том числе с позиции представителя более развитого в экономическом, политическом отношении общества, что приводило к мыслям об общей отсталости изучаемых народов. Последние жили в настолько тяжелых экономических условиях, с обнищанием основной массы населения, что наблюдатели отмечали примитивизм и порой говорили о перспективах ближайшего вымирания народов. Последующее развитие научного знания, а также исторические события XX века во многом изменили тональность и содержание заключений.

Изучение общего и особенного в культурах Центральной Азии развивалось в связи с основными тенденциями развития научного знания, в том числе с дифференциацией дисциплин, с развитием междисциплинарных направлений. Подобные работы есть в исторической науке, в этнографии, антропологии, филологии, религиоведении, психологии и др. В данном случае я обращусь к тому аспекту, который позволяет обозревать культурологическую познавательную область, рассматривая культуру как комплекс нормативно-регулятивных, ценностно-смысловых, знаково-коммуникативных и социально-воспроизводственных механизмов и средств, обеспечивающих коллективный характер форм жизнедеятельности людей (Флиер, 2000: 38). В области изучения ценностно-смыслового ядра культур я усматриваю три больших исследовательских поля, которые соответствуют определенным этапам развития научного знания. Их анализу и посвящена данная статья.

Исследования общего и особенного в культурах Центральной Азии, которые проводились в рамках отечественной науки, на мой взгляд, разворачивались на трех исследовательских полях: 1) на поле сравнительно-исторических исследований, 2) на поле исследований универсалий культур и 3) на поле исследований уникалий и универсалий культур, для которых важным стал фактор субъекта исследования (эмико-этические подходы). Каждое из них имеет разработки в виде ярких, всем уже известных публикаций, которые я представлю в данной статье в указанном ракурсе. Подчеркну, что речь идет об исследованиях общего и особенного в современных этнических культурах. Проблематика историографии кочевых культур древнего времени и раннесредневековых номад не входит в поле нашего внимания ${ }^{1}$.

\section{Сравнительно-исторические исследования}

Сравнительно-исторический анализ в научном знании восходит к началу возникновения философии, но, в целом, как научный метод сформировался в XIX веке (Моргачева, 2016). Он может включать простое сопоставление, а также историко-типологическое или историко-генетическое сравнения. Несмотря на использование слова «простое», методы сопоставления и сравнения тем не менее требуют наличия не просто максимально полной, но и систематизированной информации, которой на рубеже XIX-XX веков в исследованиях Центральной Азии не хватало, а также (как мы увидим далее) даже до середины XX века. Об этом писал, например, в 1920-е годы Г. Е. Грумм-Гржимайло (ГруммГржимайло, 2007: 498). Он отмечал отрывочность и несистематичность данных в этнографической литературе того времени, но не ставил это в вину исследователям, поскольку понимал, что помимо знания языка изучаемых народов и соответствующей подготовки необходимо было продолжительное пребывание в них. Кратковременные поездки, которые могли осуществлять исследователи рубежа XIX-XX вв., позволяли «схватывать на лету лишь то, что можно было схватить, что само бросалось в глаза; сравнительных же исследований не производилось, как и не делалось и попыток выяснения, что в этнографических явлениях у изучавшейся народности являлось продуктом ее творчества, а что взято было ей извне, причем не делалось и различия между явлениями, свойственными всей народности, и такими, которые встречались у одной из ее частей, кости или рода» (там же: 498-499).

Разумеется, сравнения нравов и обычаев, а также языков племен делались, прежде всего теми, кто мог сам наблюдать и описывать разные народы, объезжая обширные территории. Так, Г. Н. Потанин в конце XIX в. за почти четверть века совершил несколько больших экспедиций по Центральной и Восточной Азии, получил ценные сведения и по географии, и по этнографии. В 1881 г. издал «Очерки Северо-Западной Монголии» (Потанин, 1881). На территории северо-западной Монголии, как он наз-

\footnotetext{
${ }^{1}$ В этом направлении значительная историография есть в монографии известного номадоведа Н. Н. Крадина (Крадин, 2007); также истории изучения мировоззрения, духовной культуры кочевников ранних исторических этапов посвящена монография П. К. Дашковского (Дашковский, 2011).
} 
вал этот ареал, исследователь обнаружил «племена», как он пишет, трех групп: монгольской (различные племена монголов), тюркской (киргизы, урянхайцы, сарты и котоны) и китайской (китайцы, проживающие в Кобдо, Улясутае, Баркули и Хами в местности Тянь-Шаня). Везде он увидел распространение буддизма (в виде буддийских храмов, резиденций местных глав церковных округов) (там же: 77-81), зафиксировал и наличие шаманизма, при этом особо подчеркнув, у каких из народов он сохранился лучше всего (у танну-урянхайцев и урянхайцев, живущих близ Кобдо) (там же: 81-101). Эти и другие элементы культуры он рассматривал методом сопоставления: у кого что присутствует и как выглядит ${ }^{1}$.

В целом же, этнографическая наука, в рамках которой преимущественно изучались этнические культуры, практически до середины XX века была направлена прежде всего на сбор и систематизацию полевых материалов (что соответствует, например, первым трем этапам в рассмотрении периодизации развития этнографической науки в изучении тувинцев, см.: Иргит, 2010: 143). Тот факт, что мировоззрение, или в терминологии того времени - духовная культура - не изучалась столь активно, был обусловлен не только чисто научными причинами, определенной неготовностью научного знания. Помимо этого, присутствовала и идеологическая причина. Несмотря на значительный накопленный материал этнографии, ценностно-нормативная сторона культурной жизни в советское время была, как пишет П. К. Дашковский, не популярна, поскольку считалась менее важной (называлась, как мы помним, надстройкой), чем способ производства (базис) (Дашковский, 2011:17). Религия и вовсе определялась сначала как способ, к которому прибегали «малокультурные» народы для того, чтобы умилостивить природные стихии (Михайловский, 2011: 25), а позже - как фактор влияния, угнетения народных масс.

Тем не менее работы по поиску общего в культурах, безусловно, производились. Сначала они классифицировались как изучение отмирающих, уходящих в прошлое представлений, в том числе в сфере религии. Например, Е. Г. Кагаров затрагивал тематику ритуального поведения при рассмотрении этнографических параллелей монгольских обо (Кагаров, 1927). Шаманские костюмы как материальное выражение религиозных представлений у народов Сибири сразу у целого ряда этносов рассматривала Е. Д. Прокофьева (Прокофьева, 1971). В 1961 г. в свет вышел большой коллективный труд сотрудников сектора Сибири Института этнографии Академии наук СССР «Историко-этнографический атлас Сибири» (Историко-этнографический ..., 1961). В нем была обобщена и классифицирована информация о материальной культуре сибирских народов. Эти работы содержали сопоставление значительного круга сведений, которые к тому времени накопила наука.

В. П. Дьяконова анализировала религиозные представления алтайцев и тувинцев на природу и человека (Дьяконова, 1976), тем не менее, не ограничиваясь в анализе только алтайским и тувинским материалами. В сравнительном анализе, представленном в ее статье, мы видим в том числе применение метода простого сопоставления. Сначала в статье содержится описание алтайских представлений, затем - тувинских, между которых обозначена «связка»: «Тувинские представления о вселенной (оран, телегей) согласуются во многом с представлениями, отмеченными у алтайцев» (там же: 273). Указаны различия: «Итак, мы видим, что представления алтайцев (в том числе и северных) и тувинцев о подземном мире несколько отличаются в деталях, хотя его устройство имеет общие черты. Отличия носят локальный характер и несомненно отражают особенности образа жизни этих народов» (там же: 280). И отмечено общее между культурами, включая и хакасов: «У тех же алтайцев или тувинцев, а также хакасов и других тюркоязычных народов Саяно-Алтая сохранились представления о небе как высшем божестве, которому устраивали специальное летнее моление, причем у хакасов (качинцев, бельтиров и т. д.) без участия шамана, а силами стариков» (там же: 277). В работе также встречаются параллели между тувинской и монгольской культурами: «У тувинцев, как и монголов, радуга называется солона» (там же: 287). Завершила свой обзор исследователь следующими словами:

\footnotetext{
${ }^{1}$ Одним из важных трудов последних лет в этом направлении можно назвать коллективную монографию авторов - сотрудников Калмыцкого научного центра РАН, которую они предложили также рассматривать как работу «По следам Г. Н. Потанина» (Трансграничная культура ..., 2016). В ней представлен многоаспектный анализ вопросов культурной общности между ойратами Монголии и калмыками России. Как мы видим по подзаголовку, это также исследование именно сравнительно-сопоставительного направления, однако, уже выполненное с гораздо большим углублением в анализ с учетом накопленных наукой сведений и методологических приемов. При этом у авторов также вышла монография именно с сопоставительным исследованием буддийских традиций ойратов и калмыков (Буддийская традиция ..., 2015).
} 
«Заключая настоящий очерк, главным образом о представлениях алтайцев и тувинцев о вселенной и человеке, необходимо отметить некоторую пестроту этих представлений, что вполне естественно, поскольку в нем рассматривались два народа, причем, как известно, с неоднородным этническим составом. Даже внутри этих народностей, учитывая сложность этнического состава каждого из них, наблюдается неоднородность подобных представлений» (там же: 290).

Постепенно научное знание, после накопления значительного объема информации, стало переходить и на более сложные уровни сравнительного анализа. Так проблемы взаимосвязей, типологических, системных схождений между тюркской и монгольской мифологиями были разобраны С. Ю. Неклюдовым (Неклюдов, 1981). При этом, он подчеркнул, что схожесть мифологии народов двух языковых групп сложно исследовать, обсуждая «общеалтайское ядро» (в связи с нехваткой данных) ${ }^{1}$, однако можно говорить о многовековом взаимовлиянии, в том числе этноязыковом симбиозе. Тем не менее, «сходство не означает полного тождества» (там же: 184). И отличие двух этнокультурных зон (древнетюркской и древнемонгольской) прослеживается еще в археологических материалах 1 тысячелетия до н. э. Также можно противопоставить культуры, деля их на «степные» (скотоводческие) и «лесные» (охотничьи). Позже у исследователя также вышла обобщающая работа по ритуальномифологическим традициям монгольских народов (Неклюдов, 2019), в которой развивается сравнительно-типологический анализ культур как «степных» и «лесных».

Путь научного знания от сбора материала до сравнительного анализа также можно увидеть в творчестве отдельно взятого автора. Показательны здесь публикации разных лет Л. П. Потапова. В 1930-1960-е годы он сначала собирал полевые материалы по отдельным культурам, а во время и после экспедиционных работ в отдельных регионах Сибири публиковал статьи и монографии по ряду народов (алтайцев, шорцев, хакасов, тувинцев). Затем этнограф анализировал отдельные элементы общего в культурах, а спустя десятилетия представил более сложный труд - об общей религии. Так, например, сначала он писал о почитании тюрками Сибири божества Умай (Потапов, 1973), Неба (Потапов, 1978). Впоследствии также писал о сути шаманизма как религии, которую считал необходимым рассматривать в рамках родственных - сибирских - народов. В монографии «Алтайский шаманизм» (Потапов, 1991) он подразумевал шаманизм тюркоязычных народов Саяно-Алтая, генетически связанный «с древнетюркским центральноазиатским шаманизмом, на основе которого он сложился и развивался» (там же: 17).

«Древние этногенетические и этнокультурные связи упомянутых народов с историческими предками алтае-саянских народов несомненно наложили отпечаток на общность многих элементов шаманских верований и обрядов. Однако, предполагаемые характеристики и определения, выводы и заключения, вытекающие из изучения алтайского шаманизма, при всей их значимости было бы рискованно распространять на шаманизм вообще и шаманизм всех сибирских народов в целом», - также оговаривал он (там же).

Сравнительный анализ культурного материала в данной монографии выстроен уже согласно принципам структурно-функционального анализа шаманизма как религии, хотя автор не упоминал данного термина. Сначала он выделил в шаманизме отдельные его аспекты (вера в двойника, духи шамана), затем рассмотрел ритуальные функции шамана, его бубен, ритуальное облачение, шаманов как служителей культура, а затем проанализировал пантеон шаманизма, отмечая общие представления об Ульгене и Эрлике, Тенгри, Йерсу и Умай (Потапов, 1991).

В русле интересующей нас темы мы отдельно также отметим работы Н. А. Алексеева «Ранние формы религии тюркоязычных народов Сибири» (Алексеев, 1980) и «Традиционные религиозные верования тюркоязычных народов Сибири» (Алексеев, 1992), в которых автор установил этногенетические особенности религиозного мировоззрения тюркоязычных народов Сибири: якутов, алтайцев, хакасов, шорцев, тувинцев и тофаларов. При этом каждый народ рассматривался в разрезе локальных групп, а в сопоставительный анализ также включены буряты и эвенки. Несмотря на то, что исследование концентрируется вокруг шаманизма, тем не менее, автор рассматривает его на более широком фоне религиозных представлений, в том числе ранних мифологических о почитании окружающего мира.

Так, на поле сравнительно-исторических исследований работы производились, начиная от простых сопоставлений, и затем разворачиваясь в формах историко-генетических и историко-типологических сравнений. Общей исходной позицией, которая присутствует у практически всех авторов, можно

${ }^{1}$ Хотя очевидно оппонирующую точку зрения здесь представляют исследователи тэнгрианства, которые пишут об общем культе Тэнгри (неба) у тюрко-монгольских народов, напр., см.: Абаев, Аюпов, 2009. 
назвать различение двух культурных ареалов на одной территории - по языковым группам: тюркской и монгольской. Одни работы включают сравнительный анализ культур тюркоязычных и монголоязычных, но большинство сосредоточены на одном из данных ареалов.

Сравнительно-исторические исследования, разумеется, сохраняют свою актуальность и сегодня. Тем не менее, далее мы увидим, что история сравнительного изучения культур Центральной Азии также обогатилась появлением двух новых исследовательских полей, на которых также начали развиваться научные школы.

\section{Исследования универсалий культур}

В рамках развития советской этнографии в конце 1980-х - начале 1990-х годов вышли три тома важных издания из серии «Традиционное мировоззрение тюрков Южной Сибири» (Традиционное мировоззрение ..., 1988, 1989, 1990). В них была проанализирована система мировоззрения тюркоязычных народов региона: алтайцев, хакасов, тувинцев, шорцев, тофаларов, близких по происхождению, культуре и этнической истории, языки которых входят в восточно-хуннскую ветвь тюркских языков (Традиционное мировоззрение ..., 1988: 6). Эти книги считаются главным итогом научной работы Э. Л. Львовой и ее учеников-соавторов (Беликова, 2015), выпускников Томского госуниверситета, которые продолжили работы в Томске и Новосибирске. Вот уже тридцать лет три небольших красных тома стали настольными для каждого, кто изучает духовную культуру этносов южносибирского региона и кого интересуют вопросы общности мировоззрения людей, картин мира в культурах.

Благодаря воспоминаниям учеников и коллег Э. Л. Львовой, у нас есть возможность узнать, как готовилась эта работа. Коллектив планировал «показать традиционное мировоззрение народов Южной Сибири как реализацию этническими средствами общечеловеческих ценностей, а не как экзотику неразвитых культур» (цит. по: Беликова, 2015: 79). М. С. Усманова также вспоминала, что «системный (или структурный) анализ позволил нам дать иное описание народной культуры, например в первом томе “Пространство и время”, в котором новый метод был противопоставлен обычному исследовательскому приему описания этнографических реалий» (Усманова, 2015: 81).

Этот новый метод был не сразу принят и понят этнографами. Последним было сложно принять слишком вольные, как им казалось, обобщения молодых авторов, поскольку они в том числе опирались на методологию культурного универсализма. Однако, «результат чудесной авантюры», как выразилась М. С. Усманова (там же: 82), стал закономерным этапом развития этнографического знания о культурах и нашел много последователей среди востоковедов. Он позволил рассмотреть все собранное на тот момент богатство этнографических данных о культурах южносибирских тюрков в иной исследовательской оптике- не в дихотомии духовной культуры и материальной, не в аспекте религиозных верований и культах, а в общей системе взглядов на окружающий мир, которая отражалась во всех элементах культуры, в том числе и материальных предметах, и который был признан универсальной для всех культур. Ученые обозревали «контуры той системы взглядов на мир, которая в течение многих лет доминировала в обществе южно-сибирских тюрков» (Традиционное мировоззрение ..., 1988: 3). А элементами этого контура, этой системы они выбрали категории культуры (пространство, время, человек, социум и др.), анализ которых впервые представил медиевист А. Я. Гуревич на примере средневековой западной культуры (Гуревич, 1972).

Показывая результаты реконструкции мировоззрения народов одного ареала, выявляя типичные элементы, тем не менее авторы «Традиционного мировоззрения ...» старались избежать обезличивания феномена. Например, тувинская культура, будучи одним из кусочков общего паззла, не растворилась в данной реконструкции. Точно также в каждом примере, иллюстрирующем культурный материал, мы видим и элементы алтайской культуры, и хакасской. Каждая культура здесь узнаваема и легко находится в общей картине, что позволяет не только следовать логике рассуждения авторов, но и идти обратным путем - от общего к частному.

Данный подход в 1990-2000-е гг. получил достаточно широкое распространение. Тем не менее, он не был абсолютно новым для этнографической науки. Еще в монографии 1988 г. (Жуковская, 1988) и докторской диссертации 1990 г. (Жуковская, 1990). Н. Л. Жуковская охватила анализом материал монгольской культуры в широкой хронологии и рассмотрела его методом категоризации. Этот подход был развит в ее последующих работах (напр.: Жуковская, 2002). Известная востоковед проанализировала пространство и время «монгольской степи», в том числе особо остановившись на теме календаря и его элементах. Затем логически ее анализ переместился к теме календарных и других праздников, 
продуктов питания, в том числе праздничных, ритуальных, будничных. Интерес также представляют ее выводы относительно счастья по-монгольски, того, что преподносится монголами в дар, как следует себя вести в той или иной ситуации (правила этикета). Автор также показала отношение монголов к числам, особенно имеющим сакральное значение, то же самое - и к цветам культуры. В основе всей работы - те же универсалии культур, инварианты, которые Н. Л. Жуковская назвала «сквозными магистралями культуры человечества» (там же: 218) и подчеркнула важность непредвзятой оценки чужой культуры, «без чего немыслимо взаимопонимание людей, воспитанных в разных культурных традициях» (там же).

Исследование универсалий культур получило развитие и в виде углубленных исследований отдельных категорий. Так, коллектив авторов из Института монголоведения, буддологии и тибетологии СО РАН (Б. З. Нанзатов, Д. А. Николаева, М. М. Содномпилова и О. А. Шагланова) издал монографию «Пространство в традиционной культуре монгольских народов» (Пространство в традиционной ... , 2008), в которой представлен анализ не только категории пространства, но и разумеется тесно взаимосвязанной с ней категорией времени, как единства того, что понимается и проживается. В основном авторы проанализировали бурятскую традиционную культуру, тем не менее, привлекая и материалы монгольской культуры.

При этом, как отмечают исследователи:

«наряду с общностью монгольских народов, обусловленной непрерывностью этнокультурных взаимодействий, общностью литературного языка, современных исследования в области традиционной культуры монгольских народов указывают на существование разных типов культур восточноазиатской и юго-западно-азиатской, что является результатов сложного этно- и культурогенеза народов, населявших Центральную Азию. Эти различия проявляются, прежде всего, в способах освоения пространства» (там же: 6).

Универсалии культуры также выражаются в языках в виде определенных фразеологизмов, исследование которых входит в поле внимания филологов. Так, В. Н. Мушаев предлагает комплексное лингвистическое исследование фразеологизмов калмыцкого языка (Мушаев, 2015).

Поиск и содержательный анализ универсалий культур народов Центральной Азии, проживающих ныне на территории прежде всего двух соседствующих государств - России и Монголии - выполняется также международными коллективами авторов этих стран. Например, под руководством М. Ю. Шишина вышла монография «Константы культуры России и Монголии: очерки истории и теории» (Константы культуры ..., 2010). Проект интересен также и тем, что здесь речь идет не только о родственных народах региона, а и о не родственных, но граничащих между собой (например, русские и монголы), что вызвано необходимостью межкультурного диалога.

Другой международный, также российско-монгольский авторский коллектив под руководством Ю. В. Попкова для сопоставления расширил географию исследования - рассмотрел цивилизационные поля Европы и Азии, в том числе конкретизировав исследование ценностных ориентаций в разрезе констант у хакасов, тувинцев, алтайцев, казахов, монгол, а также русских (Евразийский мир ... , 2010).

Так, мы видим, что исследования универсалий культур представляют собой непосредственно культурологические исследования с акцентом на ценностно-смысловом содержании традиций и позволяют говорить о том, что содержится в представлениях людей, а также обуславливает их поведение, в целом деятельность. Наука накопила значительную сумму знаний о культурах, что позволило усложнить сравнительный анализ и сформировать целое исследовательское поле для обсуждения универсалий, констант. Но, помимо этого, подобные исследования стали возможными и в условиях социального «созревания» в целом науки. Этнические культуры, в том числе и Центральной Азии, были признаны не менее важными и интересными культурами, чем западные, вне зависимости от состояния экономического развития этнических общностей, выражающими универсальные ценностные категории.

\section{Эмико-этические исследования}

Поскольку исследования универсалий культуры сосредоточены прежде всего на изучении инвариантов культур, то следующим естественным «шагом» для науки стало появление противостоящего ему направления - исследований уникалий культур, специфических элементов в них. Соответственно, отчасти пересекаясь с проблемным полем изучения универсалий, появилось и стало расширяться исследовательское поле, в котором оказались и универсалии, и уникалии культуры, однако важным 
моментом, отличающим данное поле, стала субъектность исследователя и то, какую методологическую позицию он выбирает.

Подобный ракурс восходит к философской оппозиции понимания и объяснения, а также был выражен в понятиях етіс и etic («эмическое» и «этическое») американского лингвиста и антрополога К. Пайка (Pike, 1954-1955), по аналогии с фонетикой, изучающей звуки, имеющиеся во всех языках, и фонемикой, изучающей звуки, специфичные для одного языка. После этого в гуманитарных науках етіс стали называть культурно-специфичный подход, стремящийся понять явления, причем изнутри, глазами инсайдера; подход свойствен личности, интегрированной в культурно-исторический контекст, a etic - универсалистский, объясняющий изучаемые явления подход глазами стороннего наблюдателя, оперирующий терминами и понятиями, претендующими на универсализм и нейтральность (в нашем случае исследования универсалий культур, кросс-культурные исследования). Еще ранее, в начале XX века, об этом писал С. М. Широкогоров, русский антрополог, этнолог, который отстаивал и реализовывал в исследованиях культур генерализирующий подход, исходящий из целостного восприятия и исследования рассмотрения явлений, а не их аналитического расчленения на составные части (Shirokogoroff, 1935).

В зарубежной науке подобное направление начало развиваться с 1970-х годов, когда в социологии утверждалась стадия индигенизации, следующая за интернационализмом и которая выражала приспособление социальной теории к условиям данной страны в данный исторический период. Основания для появления этой тенденции были сформулированы Р. Мертоном в 1972 г. (Merton, 1972). Он писал о различиях в доступе к новым социологическим знаниям, обусловленных положением исследователей - тех, кто находится внутри изучаемой группы (инсайдеры), и тех, кто находится извне (аутсайдеры). Американский социолог утверждал, что группы и коллективы становятся более сознательными и солидарными в отношении доступа к знаниям о них. Это обстоятельство дало основания для формулирования учения об инсайдерском и аутсайдерском знании, содержащем реляционный момент. В антропологии с 1990-2000-х гг. это выразилось в формировании Indigenous Methodology в работах ученых - представителей коренных народов (см. об этом также: Ламажаa, 2017ab).

В российской науке, которая изучает этнические культуры, в том числе центральноазиатского региона, она наметилась в 2000-е годы параллельно кросс-культурным исследованиям (о чем я скажу далее). В центре их внимания особенности этнического мировоззрения. Эмические работы выполняются учеными-инсайдерами или с участием ученых-инсайдеров, что стало сегодня нередко подчеркиваться. Непосредственно заимствования положений зарубежной Indigenous Methodology отмечаются в работах исследователей из российских регионов, прежде всего этносоциолога У. А. Винокуровой. В частности, в 2018 г. она выступила ответственным редактором специального выпуска журнала Sibirica по проблемам Indigenous Methodology в российской науке ${ }^{1}$. В этом номере можно отметить статьи самой У. А. Винокуровой (Vinokurova, 2018), автора данной статьи (Lamazhaa, 2018), Г. П. Харючи (Kharyuchi, 2018), А. А. Базарова (Bazarov, 2018) и др. В 2019 г. ученица У. А. Винокуровой Д. В. Бурнашева защитила в Варшавском университете диссертацию (PhD) на тему «Arctic Identity: Global, National and Local Processes of Construction and Transformation» («Арктическая идентичность: глобальные, национальные и локальные процессы строительства и трансформации») ${ }^{2}$ в которой анализирует проблемы арктической идентичности в свете объединения системы знаний Запада и коренного населения.

Опыт философского исследования духовной культуры калмыков в форме эмического подхода, например, представили в коллективной монографии калмыцкие исследователи В. Н. Бадмаев, Н. Ц. Манджиев, М. С. Уланов (Бадмаев, Манджиев, Уланов, 2012). Как они подчеркнули в вводном слове: «Актуальной видится задача поиска такого философско-культурологического дискурса, который представил бы духовность нашего народа не только как целостность, но и придал бы ему ценностную, морально-нравственную укорененность, смог бы объять и глубину постоянств (преемственности) и новизну изменений» (там же: 5). Важным для себя они посчитали опору на языковую картина мира калмыков, в которой рассмотрели ряд концептов, дающих представление о национальном мен-

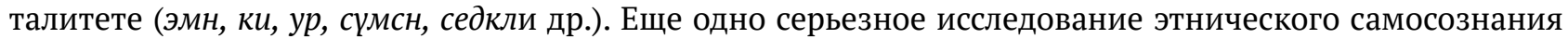
ойратов и калмыков было ранее выполнено другим калмыцким философом Б. А. Бичеевым (Бичеев, 2005). Подобным монгольским проектом можно назвать коллективную монографию российских и

\footnotetext{
${ }^{1}$ https://www.berghahnjournals.com/abstract/journals/sibirica/17/3/sibirica.17.issue-3.xml

${ }^{2}$ https://dokumenty.uw.edu.pl/dziennik/DWAL/Lists/Dziennik/monitor.aspx?ID=229
} 
монгольских авторов об учении аргабилиг, которую авторы назвали константой, осью монгольской культуры, традиционным религиозно-философским учением монголов (Учение арга билиг..., 2013). Особая рефлексия монгольской культуры также обсуждается в монографии «Монгольский мир между Востоком и Западом» под редакцией Ю. В. Попкова и Ж. Амарсанаа (Монгольский мир ... , 2014). Помимо особенностей культуры здесь анализируются вопросы цивилизационной идентичности Монголии, этнокультурные особенности восточных и западных регионов страны, геополитическое положение самой Монголии между Западом и Востоком и мн. др. В 2018 г. выходила моя монография «Национальный характер тувинцев» (Ламажаа, 2018), в которой также был сделан особый акцент на эмическом подходе.

Эмические исследования данных культур представляют интереснейший аспект представления особенного в культурах. Учитывая тот факт, что важнейшее внимание в подобных работах уделяется языковым концептам культур, то они также могут рассматриваться в русле междисциплинарных, кросс-культурных работ. Это направление в мировой науке стало развиваться сначала прежде всего в рамках психологии в конце XIX века и включало в первую очередь сопоставления поведения людей, принадлежащих разным культурам, с целью изучения связи между особенностями психики и культуры ${ }^{1}$. Однако, сегодня кросс-культурная психология направлена как на поиск культурно-специфических различий в психических процессах и явлениях, так и на установление общих для всего человечества психических переменных (Персидская, 2014: 141). Сегодня интенсивно развивается в области этнической психологии и в российской науке (Кросс-культурные и этнопсихологические ... , 2014). Подход распространился и в антропологии, и социологии, и других социальных и гуманитарных науках, которые ориентированы прежде всего на подход К. Мердока (см.: Murdock, 1945, перевод: Мердок, 2005)². Так, развивается вариант изучения культурного фрейминга близкородственных культур и этносов, причем в этико-эмическом аспекте (Мазилов, Янчук, 2013).

На мой взгляд, специалисты уже накопили определенный багаж исследований по отдельным народам Центральной Азии. В том числе вышли публикации по бурятам, монголам и русским - Т. Ц. Дугаровой (Дугарова, 2012, 2017); по тувинцам - Е. Н. Резникова, Н. О. Товуу (Резников, Товуу, 2002); по монголам (западным) - В. И. Терентьева (Терентьев, 2016аb); по алтайцам (южным) - Ж. В. Кузнецовой (Кузнецова, 2012) и мн. др. Это накопление научного «капитала» уже очевидно может стать основой и обобщениям, способствовать появлению сравнительным работ по группам этносов.

И такие попытки уже производятся. Например, исследовательская группа психологов и филологов под руководством А. И. Егоровой в 2018 г. издал «Словарь личностных качеств на тюркских языках сибирско-алтайской группы» (Словарь личностных ... , 2018). В нем рассматриваются гендерные стереотипы тюркоязычных народов (алтайцев, тувинцев, хакасов, якутов и долган) и проверяется гипотеза о совпадении универсальных (глобальных) факторов в разных языковых культурах. При этом авторы дали список личностных качеств не только тюркоязычных народов, но и термины на русском и английском языках, всего 163 терминов. Собственно же терминов на тюркских языках представлено 158, составляющих 79 пар биполярных (противоположных) личностных качеств. Они сгруппированы в шесть шкал: «Физические характеристики», «Эмоционально-волевые качества», «Отношение к труду и собственности», «Качества ума», «Моральные качества», «Отношение к себе и другим людям». Как указываютавторы, эти шкалы укладываются в пятифакторную модельличности, известнуюв психологии как «Большая пятерка» - психологическую модель, которая описывает структуру личности человека при помощи общих, относительно независимых свойств (эмоциональная стабильность / нейротизм; энергичность / экстраверсия; интеллект / открытость опыту; дружелюбие / согласие; сознательность / совестливость) (там же: 4). Пока данный словарь остается невостребованным коллегами, другими авторами ${ }^{3}$ главным образом, очевидно, потому что дается практически без комментариев и анализа выделенных терминов, личностных характеристик.

Отдельный анализ двух концептов «мужчина» и «женщина» А. И. Егорова дала в недавней авторской статье (Егорова, 2020). Опросив почти 500 человек - представителей алтайцев, тувинцев, хакасов и

\footnotetext{
${ }^{1}$ Константинов А. В. Кросс-культурные исследования [Электронный ресурс] // Большая Российская Энциклопедия. URL: https://bigenc.ru/psychology/text/2114582

${ }^{2}$ Кросс-культурный подход также предложил применять, например, для изучения общественной сложности кочевых империй Евразии Н. Н. Крадин (Крадин, 2007: 65-85). Автор рассмотрел 15 обществ номадов и выделил у кочевников и скотоводов примерно три-четыре уровня культурной и политической сложности.

3 Что, например, отмечается в отсутствии пока (на 20.08.2020) цитирований на словарь по данным РИНЦ.
} 
якутов, автор получила набор ассоциаций, связанных с гендерными ролями, и разделила их на индикаторы. В ходе исследования была выявлена и дифференциация алтайцев, тувинцев и хакасов от якутов, поскольку географическая отдаленность трех южносибирских этносов от якутского (которого исследователи потому и не относят к культурам Центральной Азии) минимизировала межэтнические контакты.

Философские обобщения по проблематике национального характера народов Центральной Азии представляла и автор данных строк (Ламажаa, 2013ab), чьи тексты также пополнили и базу данных российских ученых под редакцией А. В. Павловской и Г. Ю. Канарша «Национальные менталитеты: их изучение в контексте глобализации и взаимодействия культур» (http:/national-mentalities.ru/, см.: Канарш, 2013).

Особенностью нынешних кросс-культурных исследований, работ, обращенных к теме этнического самосознания, менталитета, становится тот факт, что материалы для анализа собираются в наши дни, когда этническое самосознание людей, представителей изучаемых этнических культур, претерпело существенные изменения после многих десятилетий советского времени и под воздействием нынешних глобализационных и вестернизационных факторов. Об этом, в частности пишут Ю. В. Попков и Л. Б. Четырова (Попков, Четырова, 2014). Поэтому кросс-культурные работы уже «оперируют» не теми традиционными культурными образами, а современными, трансформационными (Анжиганова, 2014). Отчасти этот временной фактор определяет бо́льшую актуальность исследований культур не в прежних ареалах хозяйственно-культурного типа, а с учетом их территориальной общности, необходимости диалога пограничных культур ${ }^{1}$.

\section{Заключение}

В заключение подчеркну, что в рамках отмеченных исследовательских полей вышло огромное число работ и в одной статье упомянуть, назвать все их - нет возможности. Эти исследовательские поля не разворачиваются автономно друг от друга, их выделение условно. Однако, представленный в статье методологический прием анализа познавательных полей и практик, который в общих чертах, очевидно, можно распространить и на научное знание о других культурах, позволяет увидеть, как научное знание усложнилось, обогатилось в общем русле развития научного знания - от классического к неклассическому и постнеклассическому (по В. С. Степину, см.: Степин, 2003).

На мой взгляд, в нынешнем поле эмико-этических работ есть чрезвычайно важный аспект, который связан с вопросами социального значения. Речь идет о том, что прежде всего эмические подходы, основанные на включенности исследователя в культуру, позволяют также решать задачи сохранения культурного знания и наследия. Поэтому мы можем говорить о том, что научное знание не только изучает культуры, стремясь, как раньше быть объективным, но оно стало осознавать тесную взаимосвязь с культурой и социальными условиями, точнее - свою социокультурную обусловленность. И это осознание также помогает понять особенности развития самого научного знания, выбора им определенных тем, проблем и методологических подходов в тот или иной момент истории. А осознание позволяет планировать новые стратегии исследований.

\section{СПИСОК ЛИТЕРАТУРЫ}

Абаев, Н. В., Аюпов, Н. Г. (2009) Тэнгрианская цивилизация в духовно-культурном и геополитическом пространстве Центральной Азии. Абакан : ООО «Фирма “Март”». 250 с.

Алексеев, Н. А. (1980) Ранние формы религии тюркоязычных народов Сибири. Новосибирск : Наука. 316 с.

Алексеев, Н. А. (1992) Традиционные религиозные верования тюркоязычных народов Сибири. Новосибирск : Наука, Сибирское отделение. 242 с.

Анжиганова, Л. В. (2014) Этническая культура во времени и пространстве // Этносы развивающейся России : проблемы и перспективы. Материалы седьмой Всероссийской научно-практической конференции с международным участием (Абакан, 4 декабря 2014 года). Секция 1: Кросс-культурные и этнопсихологические исследования / под общ. ред. В. Г. Морогина. Абакан. 224 с. [Электронный ресурс] // PEM: Psychology. Educology. Medicine. № 3. URL: http://wwenews.esrae.ru/pdf/2014/3/29.pdf (дата обращения: 12.09.2020).

${ }^{1}$ Это объясняет тот факт, что особым направлением кросс-культурных исследований сейчас стало изучение общего в менталитете населения Сибири - сибирская ментальность, сибирская идентичность, в которой важное значение уделяется идентичности русских, которые тоже стали коренными жителями региона. 
Бадмаев, В. Н., Манджиев, Н. Ц., Уланов, М. С. (2012) Духовная культура калмыцкого народа (опыт этнофилософского исследования). Элиста : Изд-во Калмыцкого госуниверситета. 126 с.

Беликова, О. Б. (2015) О лаборатории научной мысли Э. Л. Львовой // Сибирские исторические исследования. № 2. C. 76-80. DOI: https://www.doi.org/10.17223/2312461X/8/7

Бичеев, Б. А. (2005) Синие Волки. Мифолого-религиозные основы этнического сознания калмыков. Элиста : Изд. КалмГУ. 200 с.

Бичелдей, К. А. (2009) «Золотой век» тувиноведения и перспективы развития гуманитарных исследований в Туве // Проблемы востоковедения. № 2 (44). С. 48-55.

Буддийская традиция в Калмыкии и Западной Монголии : сакральные объекты (2015) / Э. П. Бакаева, К. В. Орлова, Н. Хишигт, Ц. Энхчимэг. М. : Наука, Восточная литература. 238 с.

Гуревич, А. Я. (1972) Категории средневековой культуры. М. : Искусство. 318 с.

Грач, А. Я. (1984) Центральная Азия - общее и особенное в сочетании социальных и географических факторов // Роль географического фактора в истории докапиталистических обществ (по этнографическим данным) / редколлегия: В. Н. Боряз, Н. А. Бутинов, Л. П. Потапов. Л. : Наука, Ленинградское отделение. 264 с. С. 113-125.

Грумм-Гржимайло, Г. Е. (2007) Западная Монголия и Урянхайский край // Урянхай. Тыва дептер : Антология научной и просветительской мысли о древней тувинской земле и ее насельниках, об Урянхае - Танну-Туве, урянхайцах - тувинцах, о древностях Тувы : в 7 т. / сост. С. К. Шойгу. М. : Слово. Т. 2. Племена Саяно-Алтая. Урянхайцы (IVв. - начало XX в.). 664 с. С. 496-639.

Дашковский, П. Д. (2011) Мировоззрение кочевников Саяно-Алтая и сопредельных территорий поздней древности и раннего средневековья (отечественная историография и современные исследования). Барнаул : Издательство Алтайского государственного университета. 244 с.

Дугарова, Т. Ц. (2012) Феноменология этнического самосознания бурят. Улан-Удэ : Изд-во Бурятского госуниверситета. 284 с.

Дугарова, Т. Ц. (2017) Культурно-ценностные ориентации российских (русских и бурят) и монгольских студентов // Вестник Российского университета дружбы народов. Серия: Психология и педагогика. Т. 14 , № 2. C. 190-120. DOI: https://doi.org/10.22363/2313-1683-2017-14-2-190-200

Дьяконова, В. П. (1976) Религиозные представления алтайцев и тувинцев о природе и человеке // Природа и человек в религиозных представлениях народов Сибири и Севера (вторая половина XIX - начало XX вв.) / отв. ред. И. С. Вдовин. Л. : Наука. 333 с. С. 268-291.

Евразийский мир: ценности, константы, самоорганизация (2010) / под ред. Ю. В. Попкова. Новосибирск : Нонпарель. 449 с.

Егорова, А. И. (2020) Психолингвистический анализ ассоциаций концептов «мужчина» и «женщина»у тюркоязычных народов Сибири // Вестник Российского университета дружбы народов. Серия: Психология и педагогика. T. 17, № 1. C. 143-158. DOI: https://doi.org/10.22363/2313-1683-2020-17-1-143-158

Жуковская, Н. Л. (1988) Категории и символика традиционной культуры монголов. М. : Наука, ГРВЛ. 196 с.

Жуковская, Н. Л. (1990) Основные категории традиционной культуры монголов : автореф. дис.... д-ра ист. н. М. 35 c.

Жуковская, Н. Л. (2002) Кочевники Монголии : Культура. Традиции. Символика : учебное пособие. М. : Восточная литература. 247 с.

Иргит, Ч. К. (2010) Становление этнографической науки в Туве // Этнографическое обозрение. № 1. С. $142-157$.

Историко-этнографический атлас Сибири (1961) / под ред. М. Г. Левина, Л. П. Потапова. М. ; Л. : Изд-во Академии наук СССР. 501 с.

Канарш, Г. Ю. (2013) От «индивидуальных» характеров - к национальным // Знание. Понимание. Умение. № 3. C. 93-98.

Кагаров, Е. Г. (1927) Монгольские «обо» и их этнографические параллели (с резюме на немецком языке) // Сборник Музея антропологии и этнографии. Вып. VI. Ленинград : Издательство Академии наук СССР. С. 115-124.

Константы культуры России и Монголии: очерки истории и теории (2010) / под общ. ред. М. Ю. Шишина, Е. В. Макаровой. Барнаул : ОАО Алтайский дом печати. 313 с.

Крадин, Н. Н. (2007) Кочевники Евразии. Алматы : Дайк-Пресс. 209 с.

Кузнецова, Ж. В. (2012) Особенности ментальности южных алтайцев // Регионология. № 3. С. $169-177$.

Ламажаa, Ч. К. (2010) Тувиноведение: область знания и социальная миссия [Электронный ресурс] // Новые исследования Тувы. № 4. C. 17-33. URL: https://nit.tuva.asia/nit/article/view/472 (дата обращения: 10.08.2020).

Ламажаa, Ч. К. (2013a) Национальный характер тюркоязычных народов Центральной Азии [Электронный ресурс] // Новые исследования Тувы. № 3. С. 69-83. URL: https://nit.tuva.asia/nit/article/view/224 (дата обращения: 10.08.2020). 
Ламажаa, Ч. К. (2013b) Национальный характер монголоязычных народов Центральной Азии [Электронный ресурс] // Новые исследования Тувы. № 4. С. 68-81. URL: https://nit.tuva.asia/nit/article/view/200 (дата обращения: 10.08.2020).

Ламажаa, Ч. К. (2017a) Тезаурусный анализ и Indigenous Methodology // Тезаурусы и тезаурусная сфера : II Академические чтения памяти Владимира Андреевича Лукова, 29 марта 2017 г. : сб. науч. трудов / отв. ред. Вал. А. Луков. М. : Изд-во Моск. гуманит. ун-та. 256 с. С. 115-126.

Ламажаа, Ч. К. (2017b) Исследования менталитета тувинцев и тенденция субъективизации гуманитарного знания // Новые исследования Тувы. № 3. С. 18-48. DOI: https://doi.org/10.25178/nit.2017.3.2

Ламажаа, Ч. К. (2018) Национальный характер тувинцев. СПб., М. : Нестор-История. 240 с.

Кросс-культурные и этнопсихологические исследования (2014) [Электронный ресурс] // PEM: Psychology. Educology. Medicine. № 3. URL: pem.esrae.ru/4-29 (дата обращения: 23.08.2020).

Мазилов, В. А., Янчук, В. А. (2013) Близкородственные этносы: исследование культурного фрейминга // РЕМ: Psychology. Educology. Medicine. № 1-1. C. 26-44.

Мердок, Дж. П. (2005) Общий знаменатель культур // Вестник культурологии. № 1. С. 202-226.

Михайловский, В. М. (2011) Шаманство (Сравнительно-этнографический очерк) // Шаманизм народов Сибири. Этнографические материалы XVIII-XX вв. : хрестоматия в 2 т. / сост. Т. Ю. Сем. СПб. : Филологический факультет СПбГУ ; Нестор-История. Т. 1.496 с. С. 25-28.

Монгольский мир: между Востоком и Западом (2014) / под ред. Ю.В. Попкова, Ж. Амарсаны. Новосибирск : Автограф. 351 с.

Моргачева, Е. Н. (2016) Сравнительно-исторический метод : обзор подходов к классификации в общественных науках // Вестник РГГУ. Серия «Психология. Педагогика. Образование». № 2 (4). С. 102-114.

Мушаев, В. Н. (2015) ӨДГӘ ЦАГИН ХАЛЬМГ КЕЛНӘ КЕЛЦ ҮГМҮД ШИНЖЛЛЬНӘ ТУСКАР (Об изучении фразеологических образований современного калмыцкого языка) // Oriental studies. Т. 8, № 1. С. 91-95.

Неклюдов, С. Ю. (1981) Мифология тюркских и монгольских народов (проблемы взаимосвязей) // Тюркологический сборник. 1977 / редакционная коллегия: А. Н. Кононов (отв. ред.), С. Г. Кляшторный, Ю. А. Петросян, С. С. Цельникер. М. : Наука, Главная редакция восточной литературы. 298 с. С. 183-202.

Неклюдов, С. Ю. (2019) Фольклорный ландшафт Монголии. Миф и обряд. М. : Индрик. 520 с.

Персидская, О.А. (2014) Дисциплинарно обусловленные вариации в кросскультурных исследованиях // Идеи и идеалы. № 2 (20). С. 138-145.

Попков, Ю. В., Четырова, Л. Б. (2014) Ресурс неотрадиционализма в формировании ценностей и идентичности у студенческой молодежи (на примере калмыков, русских, якутов и монголов) // Евразийство и мир. № 4. С. 131-145.

Потанин,Г.Н.(1881) Очерки Северо-Западной Монголии. Результаты путешествия, исполненного в 1876-1877 годах по поручению Императорского Русского географического общества. Вып. II. Материалы этнографические. СПб. : Типография В. Киршбаума. 166 с.

Потапов, Л. П. (1973) Умай - божество древних тюрков в свете этнографических данных // Тюркологический сборник, 1972. М. : Наука. 412 с. С. 265-286.

Потапов, Л. П. (1978) Древнетюркские черты почитания Неба у саяно-алтайских народов // Этнография народов Алтая и Западной Сибири. Новосибирск: Наука. С. 50-64.

Потапов, Л. П. (1991) Алтайский шаманизм. Л. : Наука, Ленинградское отделение. 321 с.

Прокофьева, Е. Д. (1971) Шаманские костюмы народов Сибири // Религиозные представления и обряды народов Сибири в XIX - начале XX века / отв. Л. П. Потапов. Л. : Наука, Ленинградское отделение. 304 с. С. 5-100.

Пространство в традиционной культуре монгольских народов (2008) / Б. З. Нанзатов, Д. А. Николаева, М. М. Содномпилова, О. А. Шагланова. М. : Восточная литература. 341 с.

Резников, Е. Н., Товуу, Н. О. (2002) Этнопсихологические характеристики народа тыва: теория и практика. М. : ПЕР СЭ. 223 с.

Рыкова, В. В. (2019) Культурное наследие Тувы: результаты анализа информационных массивов зарубежных и российских баз данных // Библиометрия, наукометрия, вебометрика. № 4. C. 89-95. DOI: https://www.doi. org/10.20913/2618-7515-2019-4-89-95

Словарь личностных качеств на тюркских языках Сибирско-Алтайской группы (2018) / науч. ред. Е. А. Егоровой. Якутск : Издательский дом СВФУ. 44 с.

Степин, В. С. (2003) Теоретическое знание : Структура, историческая эволюция. М. : Прогресс-Традиция. 743 с.

Терентьев, В. И. (2016а) Современные трансформации этнического самосознания западных монголов // Этнографическое обозрение. № 3. С. 146-161.

Терентьев, В. И. (2016b) Формирование и развитие этнического самосознания западных монголов в конце XIX - начале XXI века : автореф. дисс.... к-та ист. н. Томск. 22 с. 
Трансграничная культура : очерки сравнительно-сопоставительного исследования традиций западных монголов и калмыков (2016) / Э. П. Бакаева, К. В. Орлова, Д. Н. Музраева и др. Элиста : КалмНЦ РАН. 456 с.

Традиционное мировоззрение тюрков Южной Сибири. Пространство и время. Вещный мир (1988) / Львова Э. Л., Октябрьская И. В., Сагалаев А. М., Усманова М. С. Новосибирск : Наука, Сибирское отделение. 226 с.

Традиционное мировоззрение тюрков Южной Сибири. Человек. Общество (1989) / Львова Э. Л., Октябрьская И. В., Сагалаев А. М., Усманова М. С. Новосибирск : Наука, Сибирское отделение. 243 с.

Традиционное мировоззрение тюрков Южной Сибири. Знак и ритуал (1990) / А. М. Сагалаев, И. В. Октябрьская. Новосибирск : Наука, Сибирское отделение. 208 с.

Учение арга билиг как ось монгольской культуры (2013) / под ред. М. Ю. Шишина. Барнаул : Изд-во АлтГУ. 181 с. Флиер, А. Я. (2000) Культурология для культурологов : учебное пособие. М. : Академический проект. 496 с.

Усманова, М. С. (2015) Как писалась книга «Традиционное мировоззрение тюрков Южной Сибири» // Сибирские исторические исследования. № 2. C. 80-83. DOI: https://www.doi.org/10.17223/2312461X/8/8

Bazarov, A. (2018) The Buddhist Book Culture of the Average Person and Buryat Identity // Sibirica. Vol. 17, issue 3. P. 16-35. DOI: https://doi.org/10.3167/sib.2018.170303

Kharyuchi, G. (2018) Sacred Places in the Nenets Traditional Culture // Sibirica. Vol. 17, issue 3. Pp. 116-137. DOI: https://doi.org/10.3167/sib.2018.170310

Lamazhaa, Ch. (2018) Indigenous Methodology and Research of Tuvan Culture // Sibirica. Vol. 17, issue 3. Pp. 68-82. DOI: https://doi.org/10.3167/sib.2018.170307

Merton, R. K. (1972) Insiders and Outsiders: A Chapter in the Sociology of Knowledge // American Journal of Sociology. Vol. 78. N 1. P. 9-47. DOI: https://doi.org/10.1086/225294

Murdock, G. P. (1945) The common denominator of cultures // The science of man in the world crisis / Linton, R. (ed.). New York : Columbia University Press. 532 p. P. 123-142.

Pike, K. L. (1954-1955) Languages in relation to a unified theory of the structure of human behavior. Part I-II. Preliminary edition. Glendale, Calif.: Summer Institute of Linguistics, x, 170 p.

Shirokogoroff, S. M. (1935) Psychomental Complex of the Tungus. London: Kegan Paul, Trench, Trubner\& Co. 469 p.

Vinokurova, U. (2018) Indigenous Peoples of Siberia and the Challenges of the Twenty-First Century // Sibirica. Vol. 17, issue 3. P. 3-15. DOI: https://doi.org/10.3167/sib.2018.170302

Дата поступления: 15.09.2020 2.

\section{REFERENCES}

Abaev, N. V. and Aiupov, N. G. (2009) Tengrianskaia tsivilizatsiia v dukhovno-kul'turnom i geopoliticheskom prostranstve Tsentral'noi Azii [Tengri civilization in the spiritual, cultural and geopolitical space of Central Asia]. Abakan, OOO «Firma “Mart”». 250 p. (In Russ.).

Alekseev, N. A. (1980) Rannie formy religii tiurkoiazychnykh narodov Sibiri [Early forms of religion of the Turkic peoples of Siberia]. Novosibirsk, Nauka. 318 p. (In Russ.).

Alekseev, N. A. (1992) Traditsionnye religioznye verovaniia tiurkoiazychnykh narodov Sibiri [Traditional religious beliefs of the Turkic-speaking peoples of Siberia]. Novosibirsk, Nauka, Sibirskoe otdelenie. 242 p. (In Russ.).

Anzhiganova, L. V. (2014) Etnicheskaia kul'tura vo vremeni i prostranstve [Ethnic culture in time and space] / Etnosy razvivaiushcheisia Rossii : problemy i perspektivy [Ethnic groups of developing Russia: problems and prospects]. Proceedings of the 7th all-Russian scientific and practical conference with international participation (Abakan, December 4, 2014). Section 1: Cross-cultural and ethnopsychological research / ed. by V. G. Morogina. Abakan. 224 p. PEM: Psychology. Educology. Medicine, no. 3 [online] Available at: http://wwenews.esrae.ru/pdf/2014/3/29.pdf (access date: 12.09.2020). (In Russ.).

Badmaev, V. N., Mandzhiev, N. Ts. and Ulanov, M. S. (2012) Dukhovnaia kul'tura kalmytskogo naroda (opyt etnofilosofskogo issledovaniia) [Spiritual culture of the Kalmyk people: an ethnophilosophical study]. Elista, Izd-vo Kalmytskogo gosuniversiteta. 126 p. (In Russ.).

Belikova, O. B. (2015) O laboratorii nauchnoi mysli E. L. L'vovoi [On E. L. Lvova's laboratory of scientific thought]. Sibirskie istoricheskie issledovaniia, no. 2, pp. 76-80. DOI: https://www.doi.org/10.17223/2312461X/8/7

Bicheev, B. A. (2005) Sinie Volki. Mifologo-religioznye osnovy etnicheskogo soznaniia kalmykov [Blue Wolves. Mythological and religious foundations of the Kalmyks ' ethnic consciousness]. Elista, KalmGU Publ. 200 p. (In Russ.).

Bicheldei, K. A. (2009) «Zolotoi vek» tuvinovedeniia i perspektivy razvitiia gumanitarnykh issledovanii v Tuve [The Golden age of Tuva studies and prospects for the development of research in humanities in Tuva]. The Problems of Oriental Studies, no. 2 (44), pp. 48-55. (In Russ.).

Buddiiskaia traditsiia v Kalmykii i Zapadnoi Mongolii : sakral'nye ob"ekty [Buddhist tradition in Kalmykia and Western Mongolia: sacred objects] (2015) / E. P. Bakaeva, K. V. Orlova, N. Khishigt and Ts. Enkhchimeg. Moscow, Nauka, Vostochnaia literatura. 238 p. (In Russ.). 

Russ.).

Gurevich, A. Ya. (1972) Kategorii srednevekovoi kul'tury [Categories of medieval culture]. Moscow, Iskusstvo. 318 p. (In

Grach, A. Ya. (1984) Tsentral'naia Aziia - obshchee i osobennoe v sochetanii sotsial'nykh i geograficheskikh faktorov [Central Asia: the general and the particular in the combination of social and geographical factors]. In: Rol' geograficheskogo faktora $v$ istorii dokapitalisticheskikh obshchestv (po etnograficheskim dannym) [The role of the geographical factor in the history of pre-capitalist societies according to ethnographic data] / editorial board: V. N. Boriaz, N. A. Butinov and L. P. Potapov. Leningrad, Nauka, Leningradskoe otdelenie. 264 p. Pp. 113-125. (In Russ.).

Grumm-Grzhimailo, G. E. (2007) Zapadnaia Mongoliia i Uriankhaiskii krai. T. 3. Antropologicheskii i etnograficheskii ocherk etikh stran [Western Mongolia and Uriankhai Territory. Vol. 3. An anthropological and ethnographic study of these countries]. In: Uriankhai. Tyva depter [Uriankhai. Tyva depter]: in 7 vols. / comp. S. K. Shoigu. Moscow, Slovo. Vol. 2. Plemena Saiano-Altaia: Uriankhaitsy (IV vek - nachalo XX v.) [The tribes of the Sayan-Altai: the Uriankhai (4th - early 20th century)]. 664 p. Pp. 496-639. (In Russ.).

Dashkovskii, P. D. (2011) Mirovozzrenie kochevnikov Saiano-Altaia i sopredel'nykh territorii pozdnei drevnosti i rannego srednevekov'ia (otechestvennaia istoriografiia i sovremennye issledovaniia) [The worldview of the nomads of the SayanoAltai and adjacent territories in late antiquity and early middle ages: Russian historiography and modern research]. Barnaul, Publishing house of the Altai State University. 244 p. (In Russ.).

Dugarova, T. Ts. (2012) Fenomenologiia etnicheskogo samosoznaniia buriat [Phenomenology of ethnic identity of the Buryats]. Ulan-Ude, Buryat State University publishing house. 284 p. (In Russ.).

Dugarova, T. Ts. (2017) Kul'turno-tsennostnye orientatsii rossiiskikh (russkikh i buriat) i mongol'skikh studentov [Cultural and value orientations of Russian, Buryat, and Mongolian students]. Vestnik Rossiiskogo universiteta druzhby narodov. Seriia: Psikhologiia i pedagogika, vol. 14, no. 2, pp. 190-120. (In Russ.). DOI: https://doi.org/10.22363/2313-16832017-14-2-190-200

D'iakonova, V. P. (1976) Religioznye predstavleniia altaitsev i tuvintsev o prirode i cheloveke [Religious beliefs of Altaians and Tuvans about nature and man]. In: Priroda i chelovek $v$ religioznykh predstavleniiakh narodov Sibiri i Severa [Nature and man in the religious beliefs of the peoples of Siberia and the North] / ed. by I. S. Vdovin. Leningrad, Nauka. $336 \mathrm{p}$. Pp. 268-292. (In Russ.).

Evraziiskii mir: tsennosti, konstanty, samoorganizatsiia [Eurasian world: values, constants, self-organization] (2010) / ed. by Yu. V. Popkov. Novosibirsk, Nonparel'. 449 p. (In Russ.).

Egorova, A. I. (2020) Psikholingvisticheskii analiz assotsiatsii kontseptov «muzhchina» $\mathrm{i}$ «zhenshchina» $\mathrm{u}$ tiurkoiazychnykh narodov Sibiri [Psycholinguistic Analysis of the Associations of the Concepts of "Man" and "Woman" Typical of the Siberian Turkic Peoples]. Vestnik Rossiiskogo universiteta druzhby narodov. Seriia: Psikhologiia i pedagogika, vol. 17, no. 1, pp. 143-158. (In Russ.). DOI: https://doi.org/10.22363/2313-1683-2020-17-1-143-158

Zhukovskaia, N. L. (1988) Kategorii i simvolika traditsionnoi kul'tury mongolov [The categories and symbols of traditional culture of the Mongols]. Moscow, Nauka, GRVL. 196 p.

Zhukovskaia, N. L. (1990) Osnovnye kategorii traditsionnoi kul'tury mongolov [The main categories of the traditional culture of the Mongols]: Abstract of Diss.... Doctor of History. Moscow. 35 p.

Zhukovskaia N. L. (2002) Kochevniki Mongolii : Kul'tura. Traditsii. Simvolika [Nomads of Mongolia: Culture. Traditions. Symbolism]. Moscow, Vostochnaia literatura. 247 p. (In Russ.).

Irgit, Ch. K. (2010) Stanovlenie etnograficheskoi nauki v Tuve [The Development of Ethnography in Tuva]. Etnograficheskoe obozrenie, no. 1, pp. 142-157. (In Russ.).

Istoriko-etnograficheskii atlas Sibiri [A historical and ethnographic atlas of Siberia] (1961) / ed. by M. G. Levin and L. P. Potapov. Moscow, Leningrad, Izd-vo Akademii nauk SSSR. 501 p. (In Russ.).

Kanarsh, G. Yu. (2013) Ot «individual'nykh» kharakterov - k natsional'nym [From "individual” characters to national ones]. Znanie. Ponimanie. Umenie, no. 3, pp. 93-98. (In Russ.).

Kagarov, E. G. (1927) Mongol'skie «obo» i ikh etnograficheskie paralleli (s reziume na nemetskom iazyke) [Mongolian "obo" and their ethnographic parallels (with a summary in German)]. In: Sbornik Muzeia antropologii i etnografii, vol. VI. Leningrad, Izdatel'stvo Akademii nauk SSSR. Pp. 115-124. (In Russ.).

Konstanty kul'tury Rossii i Mongolii: ocherki istorii i teorii [Cultural constants of Russia and Mongolia] (2010) / ed. by M. Yu. Shishin and E. V. Makarova. Barnaul, OAO Altaiskii dom pechati. 313 p. (In Russ.).

Kradin, N. N. (2007) Kochevniki Evrazii [Nomads of Eurasia]. Almaty, Daik-Press. 209 p. (In Russ.).

Kuznetsova, Zh.V. (2012) Osobennosti mental'nosti iuzhnykh altaitsev [Peculiarities in mentality of southern Altaians]. Regionologiia, no. 3, pp. 169-177. (In Russ.).

Lamazhaa, Ch. K. (2010) Tuvinovedenie: oblast' znaniia i sotsial'naia missiia [Tuvan studies: a demesne of knowledge and a social mission]. New Research of Tuva, no. 4, pp. 17-33 [online] Available at: https://nit.tuva.asia/nit/article/view/472 (access date: 10.08.2020) (In Russ.).

Lamazhaa, Ch. K. (2013a) Natsional'nyi kharakter tiurkoiazychnykh narodov Tsentral'noi Azii [National character of Turkic people in Central Asia]. New Research of Tuva, no. 3, pp. 69-83 [online] Available at: https://nit.tuva.asia/nit/article/ view/224 (access date: 10.08.2020) (In Russ.). 
Lamazhaa, Ch. K. (2013b) Natsional'nyi kharakter mongoloiazychnykh narodov Tsentral'noi Azii [National character of Mongolian-speaking peoples of Central Asia]. New Research of Tuva, no. 4, pp. 68-81 [online] Available at: https://nit. tuva.asia/nit/article/view/224 (access date: 10.08.2020) (In Russ.).

Lamazhaa, Ch. K. (2017a) Tezaurusnyi analiz i Indigenous Methodology [Thesaurus analysis and Indigenous methodology]. In: Tezaurusy i tezaurusnaia sfera : II Akademicheskie chteniia pamiati Vladimira Andreevicha Lukova, 29 marta 2017 g. [Thesaurus and thesaurus sphere: II Academic readings in memory of Vladimir Andreevich Lukov, March 29, 2017]: a collection of articles / ed. by Val. A. Lukov. Moscow, Izd-vo Mosk. gumanit. un-ta. 256 p. Pp. 115-126. (In Russ.).

Lamazhaa Ch. K. (2017b) Issledovaniia mentaliteta tuvintsev i tendentsiia sub"ektivizatsii gumanitarnogo znaniia [Studies of mindset of Tuvans and the subjectivity trend in academic knowledge]. New Research of Tuva, no. 3, pp. 18-48. (In Russ.). DOI: https://doi.org/10.25178/nit.2017.3.2

Lamazhaa, Ch. K. (2018) Natsional'nyi kharakter tuvintsev [National character of Tuvans]. Moscow, St. Petersburg, Nestor-Istoriia. 240 p. (In Russ.)

Kross-kul'turnye i etnopsikhologicheskie issledovaniia [Cross-cultural and ethnopsychological research] (2014). PEM: Psychology. Educology. Medicine, no. 3 [online] Available at: pem.esrae.ru/4-29 (access date: 23.08.2020). (In Russ.)

Mazilov, V. A. and Yanchuk, V. A. (2013) Blizkorodstvennye etnosy: issledovanie kul'turnogo freiminga [Closely related ethnic groups: a study in cultural framing]. PEM: Psychology. Educology. Medicine, no. 1-1, pp. 26-44. (In Russ.)

Murdock, G. P. (2005) Obshchii znamenatel' kul'tur [The common denominator of cultures]. Vestnik kul'turologii, no. 1, pp. 202-226. (In Russ.)

Mikhailovskii, V. M. (2011) Shamanstvo (Sravnitel'no-etnograficheskii ocherk) [Shamanism: an essay in comparative ethnography]. In: Shamanizm narodov Sibiri. Etnograficheskie materialy XVIII-XX vv. [Shamanism of the peoples of Siberia. Ethnographic materials of the $18^{\text {th }}-20^{\text {th }}$ centuries]: an anthology: in 2 vol. / comp. by T. Yu. Sem. St. Petersburg, Filologicheskii fakul'tet SPbGU; Nestor-Istoriia. Vol. 1.496 p. Pp. 25-28. (In Russ.)

Mongol'skii mir: mezhdu Vostokom i Zapadom [The Mongolian world: between East and West] (2014) / Yu. V. Popkov and Zh. Amarsany (eds). Novosibirsk, Avtograf. 351 p. (In Russ.).

Morgacheva, E. N. (2016) Sravnitel'no-istoricheskii metod : obzor podkhodov k klassifikatsii v obshchestvennykh naukakh [Comparative historical method: a review of approaches to classification in the social sciences]. Vestnik RGGU. Seriia «Psikhologiia. Pedagogika. Obrazovanie», no. 2 (4), pp. 102-114. (In Russ.)

Mushaev, V. N. (2015) On Studying Phraseological Units of the Contemporary Kalmyk Language. Oriental studies, vol. 8, no. 1, pp. 91-95. (In Mong.)

Nekliudov, S. Yu. (1981) Mifologiia tiurkskikh i mongol'skikh narodov (problemy vzaimosviazei) [Mythology of the Turkic and Mongolian peoples: issues of interconnection]. In: Tiurkologicheskii sbornik. 1977 [Turkological collection. 1977]/ editorial board: A. N. Kononov (ed.), S. G. Kliashtornyi, Yu. A. Petrosian and S. S. Tsel'niker. Moscow, Nauka, Glavnaia redaktsiia vostochnoi literatury. 298 p. Pp. 183-202. (In Russ.)

Nekliudov, S. Yu. (2019) Fol'klornyi landshaft Mongolii. Mif i obriad [of Mongolia's folk landscape: Myth and rite]. Moscow, Indrik. 520 p. (In Russ.)

Persidskaia, O. A. (2014) Distsiplinarno obuslovlennye variatsii v krosskul'turnykh issledovaniiakh [Disciplinary variations in cross-cultural studies]. Idei i idealy, no. 2 (20), pp. 138-145. (In Russ.)

Popkov, Yu. V. and Chetyrova, L. B. (2014) Resurs neotraditsionalizma v formirovanii tsennostei i identichnosti u studencheskoi molodezhi (na primere kalmykov, russkikh, iakutov i mongolov) [The resource of neo-traditionalism in the formation of values and identities of the student youth: the cases of Kalmyks, Russians, Yakuts and Mongols]. Evraziistvo i mir, no. 4, pp. 131-145. (In Russ.)

Potanin, G. N. (1881) Ocherki Severo-zapadnoi Mongolii: Rezul'taty puteshestviya, ispolnennogo v 1876-1877 g. po porucheniyu Imperatorskogo Russkogo geograficheskogo obshchestva chlenov sotrudnikom onogo G. N. Potaninym [Sketches of Northwestern Mongolia: summarizing the results of the 1876-1877 trip commissioned by the Imperial Russian Geographical Society and undertaken by its employed associate G. N. Potanin]. Vol II. St. Petersburg, Tipografiia V. Kirshbauma. 166 p. (In Russ.).

Potapov, L. P. (1973) Umai - bozhestvo drevnikh tiurkov v svete etnograficheskikh dannykh [Umay, the deity of the ancient Turks, in the light of ethnographic data]. In: Tiurkologicheskii sbornik, 1972 [Turkological collection. 1972]. Moscow, Nauka. 412 p. Pp. 265-286. (In Russ.)

Potapov, L. P. (1978) Drevnetiurkskie cherty pochitaniia Neba u saiano-altaiskikh narodov [Ancient Turkic features of sky worship among the Sayan-Altai peoples]. In: Etnografiia narodov Altaia i Zapadnoi Sibiri [Ethnography of the peoples of Altai and Western Siberia]. Novosibirsk, Nauka. Pp. 50-64. (In Russ.) Russ.)

Potapov, L. P. (1991) Altaiskii shamanism [Altaic shamanism]. Leningrad, Nauka, Leningradskoe otdelenie. 321 p. (In

Prokof'eva, E. D. (1971) Shamanskie kostiumy narodov Sibiri [Shamanic costumes of the peoples of Siberia]. In: Religioznye predstavleniia i obriady narodov Sibiri $v$ XIX - nachale XX v. [Religious representations and rites of the peoples of Siberia in the $19^{\text {th }}$ and early 20 th century] / ed. by L. P. Potapov. Leningrad, Nauka. 301 p. Pp. 5-100. 
Prostranstvo $v$ traditsionnoi kul'ture mongol'skikh narodov [Space in the traditional culture of the Mongolian peoples] (2008) / Nanzatov B. Z., Nikolaeva D. A., Sodnompilova M. M. and Shaglanova O. A. Moscow, Vostochnaia literatura. 341 p. (In Russ.).

Reznikov, E. N. and Tovuu, N. O. (2002) Etnopsikhologicheskie kharakteristiki naroda tyva: teoriia i praktika [Ethnopsychological characteristics of the Tuvan people: theory and practice]. Moscow, PER SE. 223 p. (In Russ.).

Rykova, V.V. (2019) Kul'turnoe nasledie Tuvy: rezul'taty analiza informatsionnykh massivov zarubezhnykh i rossiiskikh baz dannykh [Tuvan cultural heritage: the results of analysis of information arrays in foreign and domestic databases]. Proceedings of SPSTL SB RAS, no. 4, pp. 89-95. DOI: https://www.doi.org/10.20913/2618-7515-2019-4-89-95

Slovar' lichnostnykh kachestv na tiurkskikh iazykakh Sibirsko-Altaiskoi gruppy [Dictionary of personal qualities in the Turkic languages of the Siberian-Altai group] (2018) / ed. by E. A. Egorova. Yakutsk, Izdatel'skii dom SVFU. 44 p. (In Russ.).

Stepin, V. S. (2003) Teoreticheskoe znanie : Struktura, istoricheskaia evoliutsiia [Theoretical knowledge: structure and historical evolution]. Moscow, Progress-Traditsiia. 743 p. (In Russ.).

Terent'ev, V. I. (2016a) Sovremennye transformatsii etnicheskogo samosoznaniia zapadnykh mongolov [Current transformations of ethnic identity among the western mongolians)]. Etnograficheskoe obozrenie, no. 3, pp. 146-161. (In Russ.).

Terent'ev, V. I. (2016b) Formirovanie i razvitie etnicheskogo samosoznaniia zapadnykh mongolov v kontse XIX - nachale XXI veka [Formation and development of ethnic identity of Western Mongols in the late $19^{\text {th }}$ - early $21^{\text {st }}$ century]: Abstract of Diss. ... Candidate of History. Tomsk. 22 p. (In Russ.).

Transgranichnaya kul'tura: Ocherki sravnitel'no-sopostavitel'nogo issledovaniya traditsii zapadnykh mongolov i kalmykov [Cross-border culture: comparative research sketches of the traditions of the western Mongols and Kalmyks] (2016). E. P. Bakaeva et al. Elista, Kalmyk Scientific Center of RAS. 456 p. (In Russ.).

Traditsionnoe mirovozzrenie tiurkov Iuzhnoi Sibiri. Prostranstvo i vremia. Veshchnyi mir [The traditional worldview of Turkic peoples of South Siberia. Space and time. The outer world] (1988) / ed. by L'vova E. L., Oktiabr'skaia I. V., Sagalaev A. M. and Usmanova M. S. Novosibirsk, Nauka. 226 p. (In Russ.).

Traditsionnoe mirovozzrenie tiurkov Iuzhnoi Sibiri. Chelovek. Obshchestvo [The traditional worldview of Turkic peoples of South Siberia. Person. Society] (1989) / L'vova E. L., Oktiabr'skaia I. V., Sagalaev A. M., Usmanova M. S. Novosibirsk, Nauka, Sibirskoe otdelenie. 243 p. (In Russ.).

Traditsionnoe mirovozzrenie tiurkov Iuzhnoi Sibiri. Znak i ritual [The traditional worldview of Turkic peoples of South Siberia. Sign and ritual] (1990) / A. M. Sagalaev and I. V. Oktiabr'skaia. Novosibirsk, Nauka, Sibirskoe otdelenie. 208 p. (In Russ.).

Uchenie argabilig kak os' mongol'skoi kul'tury [The teaching of Arga Bilig as the axis of Mongolian culture] (2013) / ed. by M. Yu. Shishin. Barnaul, Izd-vo AltGU. 181 p. (In Russ.).

Flier, A. Ya. (2000) Kul'turologiia dlia kul'turologov [Culturology for culturologists]: a textbook. Moscow, Akademicheskii proekt. 496 p. (In Russ.).

Usmanova, M. S. (2015) Kak pisalas' kniga «Traditsionnoe mirovozzrenie tiurkov Iuzhnoi Sibiri» [How “The Traditional world Outlook of Turks in South Siberia” was written]. Siberian Historical Research, no. 2, pp. 80-83. DOI: https://www.doi. org/10.17223/2312461X/8/8

Bazarov, A. (2018) The Buddhist Book Culture of the Average Person and Buryat Identity. Sibirica, vol. 17, issue 3, pp. 16-35. DOI: https://doi.org/10.3167/sib.2018.170303

Kharyuchi, G. (2018) Sacred Places in the Nenets Traditional Culture. Sibirica, vol. 17, issue 3, pp. 116-137. DOI: https:// doi.org/10.3167/sib.2018.170310

Lamazhaa, Ch. (2018) Indigenous Methodology and Research of Tuvan Culture. Sibirica, vol. 17, issue 3, pp. 68-82. DOI: https://doi.org/10.3167/sib.2018.170307

Merton, R. K. (1972) Insiders and Outsiders: A Chapter in the Sociology of Knowledge. American Journal of Sociology, vol. 78, no. 1, pp. 9-47. DOI: https://doi.org/10.1086/225294

Murdock, G. P. (1945) The common denominator of cultures. In: The science of man in the world crisis / Linton, R. (ed.). New York, Columbia University Press. 532 p. P. 123-142.

Pike, K. L. (1954-1955) Languages in relation to a unified theory of the structure of human behavior. Part I-II. Preliminary edition. Glendale, Calif., Summer Institute of Linguistics, x, $170 \mathrm{p}$.

Shirokogoroff, S. M. (1935) Psychomental Complex of the Tungus. London, Kegan Paul, Trench, Trubner\& Co. 469 p.

Vinokurova, U. (2018) Indigenous Peoples of Siberia and the Challenges of the Twenty-First Century. Sibirica, vol. 17, issue 3, pp. 3-15. DOI: https://doi.org/10.3167/sib.2018.170302

Submission date: 15.09.2020. 